Journal Economics and Management (JECMA)

Volume 2, No. 01, Agustus 2021, p. 10-18

\title{
Analisis Bauran Pemasaran (Marketing Mix) pada Telor Asin UD. Ratu Sari
}

\author{
Marketing Mix Analysis on UD Salted Eggs. Queen Sari \\ Ahmad Farizal ${ }^{* 1}$, Gian Fitralisma ${ }^{2}$
*1, $^{2}$ Program Studi Manajemen, Fakultas Ekonomi dan Bisnis, Universitas Muhadi Setiabudi, Brebes, \\ Indonesia \\ e-mail:*1afarizal16@gmail.com,2,gianfitralisma@umus.ac.id.
}

\begin{abstract}
ABSTRAK
Pemasaran produk khas daerah menjadi faktor penting selaian mengenai laba dan perkembangan perusahaan ini juga mengenai ikut serta dalam mengabangkan produk daerah yang menjadi warisan tak bagi kota Brebes. Dalam implementasi bauran pemasaran produk, harga, tempat dan promosi mendapatkan bahwa bauran pemasaran pada promosi dan tempat UD. Ratu sari kurang efektif dalam menjalankannya karena sudah era digital tetapi perusahaan tidak mencoba menjual di starup digital dan tempat penjualan yang menggunakan tempat produksi seadanya membuat profil usaha kurang menarik. Tujuan peneliti adalah untuk mengetahui bauran pemasaran produk, harga, tempat dan promosi di UD. Ratu Sari, Jenis penelitian yang digunakan adalah penelitian kualitatif yaitu jenis penelitian deskriptifyang merupakan jenis peneltian studi kasus karena melakukan eksplorasi mendalam terhadap aktifitas pemasaran pada objek penelitian. Dari 4 bauran pemasaran yaiu produk tempat,harga dan promosi yang menjadi kelemahan di UD ratu sari adalah pomosi dan tempat sedangkan yang menjadi keunggulan adalah produk dan harga.
\end{abstract}

Kata kunci : produk, harga, tempat, promosi.

\begin{abstract}
Marketing of local specialty products is an important factor in addition to the profit and development of this company as well as participating in the generation of regional products that are not inherited by the city of Brebes. In the implementation of product marketing mix, price, place and promotion get that the marketing mix at promotion and place of UD. Ratu Sari is less effective in running it because it is in the digital era, but the company does not try to sell at digital startups and sales places that use makeshift production sites to make the business profile less attractive. The research objective is to determine the product marketing mix, price, place and promotion at UD. Ratu Sari, the type of research used is qualitative research, namely descriptive research which is a type of case study research because it carries out in-depth exploration of marketing activities on the research object. Of the 4 marketing mixes, namely product, place, price and promotion, the weaknesses at UD Ratu Sari are promotion and place, while the advantages are product and price.
\end{abstract}

Keywords: product, price, place, promotion.

\section{INTRODUCTION}

Perkembangan dunia usaha khususnya UKM/UMKM/IKM yang cenderung pada industri-industri rumahan dan pengembangan makanan khas daerah tertentu sekarang sudah menjadi gaya baru di masyarakat Indonesia, perkembangan usaha ini sudah mulai beradaptasi dengan era globalisasi sehingga membantu perkembangan perekonomian indonesia di semua sektor. Sektor industri misanya sektor ini merupakan salah satu sektor prioritas pembangunan ekonomi, dengan tetap memperhatikan dan mendorong sektor lain untuk ikut maju bersama

Brebes adalah daerah yang sangat berpotoensial dalam pembuatan dan pengembangan hasil pertanian dan telor asin, sebagai sentral produksi telor asin yang telah di tetapkan sebagai warisan budaya tak benda, Brebes memiliki sejarah yang tidak bisa lepas dari budaya yang melahirkan sebuah ketrampilan membuat makanan ringan sampai kerajinan tangan seperti telor asin dan batik khasnya. Ketrampilan membuat telor asin Brebes telah diwarisi secara alamiah atau

Submitted: Juli 2021, Accepted: Agustus 2021, Published: Agustus 2021

ISSN: 2746-0568 (online), Website: http://jurnal.umus.ac.id/index.php/jecma 
Journal Economics and Management (JECMA), Volume 2, No. 01, Agustus 2021, p. 10-18

turun temurun sehingga pembuatan telor asin ini berpadu dengan kegiatan perekonomian masyarakat yang terus berjalan dari generasi yang satu ke generasi selanjutnya.

Menurut Hesty dan Iqbal Keberadaan internet memberikan akses konsekuensi tidak hanya pada perubahan gaya hidup modern namun juga merubah perilaku individu dalam melakukan aktivitas pembelian produk barang dan jasa secara daring (online) [1] Persaingan usaha yang terjadi di Indonesia kini semakin kompetiti menuntut para pelaku usaha agar memperhatikan efesiensi dan efektifitas dalam penggunaan sumber daya yang dimiliki agar tujuan usahanya tercapai. Salah satu faktor pendukung keberhasilan suatu perusahan yaitu cara pemasaran atau setrategi pemasarannya yang dipakai, kegiatan pemasaran meliputi produk, penerapan harga, kebijakan distribusi dan cara promos, yang sering di sebut bauran pemasaran. Setrategi ini tentu harus mampu memberikan kontribusi terhadap pencapaian tujuan perusahaan yaitu peningkatan mutu dan luasnya jaringan pemasaran. Menurut Rachmawati Bauran pemasaran adalah strategi produk, promosi,tempat, dan penentuan harga yang bersifat unik dan dirancang untuk bisa menghasilkan pertukaran yang saling menguntungkan dengan pasar yang inginkan[1].

Perusahaan selama ini memasarkan produk telor asin hanya melalui relasi yang selama ini terjalin erat memasok berbagai rumah makan seperti Warung Tegal (WARTEG), rumah makan Padang, restoran dan berbagai outlet serta pasar di sekitar Jakarta, Tanggerang, Bekasi, Depok dan beberapa di kota jawa barat permasalahan yang sekarang dihadapi adalah perusahaan sedang berupaya agar bisa mengikuti perkembangan zaman dengan menjual secara oline sekaligus memperluas pangsa pasar. Menurut Hesty dan Iqbal Perubahan gaya hidup individu di tengah maraknya e-commerce dapat menjadi peluang baru bagi perusahaan untuk memperluas pangsa pasar dan menambah volume penjualan dengan melakukan inovasi terus menerus serta fleksibilitas penjualan[2].

Menurut Nisa Novia Avien Christy dan Dwi Widi Pratito untuk mengembangkan pasar pelu adanya inovasi seperti diversifikasi produk sehingga lebih banyak pilihan dan varian[3]. Agar usaha ini terus berjalan dan selalu mengikuti perkembangan zaman perlu adanya memperluas pangsa pasar tetapi sebelum itu sangat diperlukan melakukan strategi bauran pemasaran atau marketing mix yang diperlukan untuk meningkatkan volume penjualan dan meningkatkan laba. Strategi pemasaran untuk memenangkan pasar di wilayah Yogyakarta terkait dengan operator seluler dapat menghasilkan 3 klaster 1 (layanan, klaster 2 (harga kartu perdana), dan 3 (biaya telepon) [2]..Menurut Rina Rahmawati Pemasaran lebih condong dipandang dari segi seni daripada ilmu, maka dari itu seorang ahli dalam pemasaran tergantung lebih banyak pada ketrampilan pertimbangan dalam membuat kebijakan daripada berorientasi pada ilmu tertentu [1]. Penjualan sangat penting untuk menentukan kelangsungan produksi bagi perusahaan, penjual dituntut untuk mampu dan memiliki bakat serta keahlian untuk mempengaruhi orang lain, bakat seperti ini yang tidak semua orang bisa memiliki karena tidak mudah untuk mengarahkan kemauan calon pembeli dengan cara mengemukakan berbagai alasan serta pendapatnya di khalayak ramai atau di depan orang lain.

\section{LITERATURE REVIEW}

\section{Bauran Pemasaran}

Menurut Cristian Bauran pemasaran adalah suatu perangkat yang terbentuk dari produk, harga, promosi dan distribusi, yang didalamnya akan menentukan tingkat keberhasilan pemasaran dan semua itu dimaksudkan agar mendapatkan respon yang positif dari pasar sasaran yang diinginkan [3]. Menurut Nisa Novia Avien Christy dan Dwi Widi Pratito strategi pemasaran merupakan rencana yang menjelaskan ekspektasi perusahaan akan dampak yang terjadi dari berbagai aktivitas atau program pemasaran terhadap permintaan produk atau lini produknya di pasar sasaran tertentu [4]. Menurut Hesti dan Iqbal Bauran pemasaran yang terdiri dari produk, harga, lokasi, dan promosi merupakan salah satu alat strategi pemasaran yang pada realisasinya 
Journal Economics and Management (JECMA), Volume 2, No. 01, Agustus 2021, p. 10-18

memerlukan pemahaman mendalam dari perusahaan untuk menggabungkan faktor-faktor tersebut agar memaksimalkan kesuksesan aktivitas pemasaran perusahaan [1] Menurut Rina Rachmawati Rerangkaian variabel yang dapat dikontrol dan tingkat variabel yang dimaksimalkan oleh perusahaan untuk mempengaruhi pasar yang menjadi sasaran dan mencapai tujuan pemasaran perusahaan [5].

\section{Produk (Product)}

Menurut Rachmawati produk adalah keseluruhan rancangan, objek dan proses yang dapat memberikan sejumlah merek, kemasan, labeling, layanan pelengkap dan jaminan [1].

Menurut Christian A.D Selang 2013 Intensitas kompetensi di pasar memaksa perusahaan harus mengupayakan adaptasi produk yang tinggi guna meraih keunggulan yang kompetitif atas pesaingnya dan keunggulan suatu produk berupa salah satu faktor penentu dari sebuah kesuksesan produk baru, dimana kesuksesan sebuah produk tersebut diukur dengan sebuah parameter jumlah penjualan produk[4]. Menurut Nisa Novia Avien Christy dan Dwi Widi Pratito Pemahaman subjektif dari produsen atas sesuatu yang bisa ditawarkan sebagai usaha untuk mencapai tujuan sebuah organisasi berdasarkan pemenuhan kebutuhan dan keinginan konsumen, setara dengan kompetensi dan kemampuan organisasi serta daya beli pasar [3]. Menurutr Utami Produk bisa diartikan sebagai sistem fitur, fungsi, manfaat dan penggunaan yang digunakan untuk memberikan kepuasan konsumen[2]. Menurut Utami Produk mampu diinovasikan dengan memanfaatkan cara bauran dan atribut produk untuk mempegaruhi konsumen agar membeli produk, dalam prilaku konsumen, produk bisa diartikan salah satu indikator dalam melakukan pencairan, pembelian, penggunaan dan evaluasi produk di pasaran [2].

Menurut I. G. Marendra Produk adalah pengertian subjektif oleh produsen dari sesuatu yang biasa ditawarkan sebagai bentuk usaha agar mencapai tujuan organisasi melalui pemenuhan kebutuhan dan kegiatan konsumen [5]. Menurut I. G. Marendra 2018 Produk adalah bentuk barang ataupun jasa yang ditawarkan kepada pasar maupun produsen agar dapat menarik perhatian pembeli atau konsumen sehingga dapat memenuhi keperluan konsumen [5]. Menurut petrus jayabaya dan putu nina mediawati melihat adanya suatu peluang dimanfaatkan dan diinovasikan agar produk mempunyai pasar yang lebih luas khususnya pasar digital [6]. Menurut farida produk adalah barang maupun jasa yang berkaitan dengan kualitas yang ditawarkan dengan harga terjangkau dan menjadi sasaran pasar [7]. Menurut Ulus Produk adalah segala bentuk hasil produksi yang bisa ditawarkan produsen untuk diperhatikan, dicari, dibeli, digunakan dan di konsumsi pasar menjadi kebutuhan konsumen [8]. Menurut Kamaratih produk konsumen merupakan barang dan jasa yang dibeli konsumen akhir untuk dijadikan konsumsi pribadi sedangkan Produk industri adalah produk yang dibeli untuk diolah lebih lanjut atau dalam artian produk mentah atau produk belum jadi yang dibeli untuk di proses menjadi produk matang atau produk jadi[9].

\section{Price (Harga)}

Menurut Rachmawati Harga adalah salah satu alat untuk mengukur kualitas barang atau jasa dan lainnya yang di transaksikan untuk memperoleh hak milik atau pengunaan jasa ataupun suatu barang [5]. Menurut Utami Harga adalah satu diantara komponen pemasaran yang terdapat didalam bauran pemasaran yang bisa mempengaruhi permintaan dan merupakan komponen penggerak posisi produk yang akan mempengaruhi produk akan dipersepsikan oleh konsumen dibandingkan dengan produk pesaing [1]. Menurut Hermawan Harga merupakan satu-satunya dari sekian unsur bauran pemasaran yang memberikan pemasukan atau pendapatan bagi perusahaan, disamping itu unsur bauran pemasaran bersifat fleksibel bisa berubah-ubah mengikuti persepsi pasar[10]. Menurut Christian A.D Selang sejumlah uang yang digunakan untuk mendapatkan beberapa barang ataupun dari pelayanan, sehingga banyak perusahaan melakukan pendekatan terhadap penentu harga berlandaskan tujusan yang akan dicapai, tujuannya dapat berupa meningkatnya penjualan, mempertahankan market share, mempertahankan stabilitas harga, mendapat keuntungan lebih banyak dan lain-lain[4]. Menurut Nisa Novia Avien Christy dan Dwi Widi Pratito Harga merupakan sejumlah uang ditambah 
Journal Economics and Management (JECMA), Volume 2, No. 01, Agustus 2021, p. 10-18

beberapa produk kalau memungkinkan yang ditambah agar bisa mendapatkan sejumlah produk dan pelayaan[3]. Menurut Utami Pandangan harga bagi para konsumen merupakan keseluruhan biaya yang harus dikeluarkan konsumen yang bersifat moneter yang digunakan agar dapat memiliki, membeli dan memanfaatkan produk serta pelayanan yang ditawarkan produk [2].

Menurut Gede Marendra Harga bisa diartikan sebagai sejumlah uang yang wajib diberikan atau ditukar ketika melakukan pembelian produk ataupun jasa[5]. Menurut Farida Elemen penting dari bauran pemasaran karena menjadi kunci bagi konsumen untuk melakukan transaksi khususnya bagi sasaran perusahaan kelas ekonomi menengah kebawah yang sangat selektif ketika melihat harga barang [7]. Menurut Ulus Harga menjadi satu-satunya instrumen dari bauran pemasaran yang menghasilkan penerimaan penjualan[8]. Menurut Kamaratih Harga yaitu ukuran untuk pembayaran suatau barang atau jasa [9].

\section{Tempat (Place)}

Menurut Christian A.D Selang keputusan dalam memilih tempat ada kaitannya dengan komitmen berjangka panjang terhadap suatu aspek-aspek yang bersifat kapital insentif, maka dengan seperti itu perusahaan benar-benar harus mempertimbangkan dan lebih selektif dalam memilih lokasi yang lebih responsif terhadapt situasi ekonomi, demografi, budaya, dan persaingan dimasa mendapat[4]. Menurut Hermawan 2018 Strategi yang bisa menentukan dimana dan bagaimana seseorang menjual produk tertentu[10]. Menurut Rachmawati Yang terpenting dalam setrategi ini adalah menetapkan sebuah lokasi dan distributor dimana konsumen dapat melihat dan juga membeli barang yang ditawarkan itu karena dalam elemen bauran pemasaran ini berarti lokasi yang merupakan keputusan organisasi mengenai tempat operasinya dengan semua kegiatan-kegiatan organisasinya. Keputusan dalam pemilihan lokasi menjadi nilai investasi yang paling mahal, sebab lokasi bisa dikatakan menentukan ramai atau tidaknya dilihat dari pengunjungnya[1]. Menurut Nisa Novia Avien Christy dan Dwi Widi Pratito Kegiatan pemasaran yang berusaha agar mempermudah penyampaian barang atau jasa produsen kepada konsumen hingga penggunaanya menjadi sesuai yang diperlukan seperti jenis, jumlah dan harga[3].

\section{Promosi (Promotion)}

Menurut Hermawan Promosi merupakan setrategi di dalam bauran yang sangat penting dilaksanakan oleh perusahaan dalam upaya menjual produk ataupun jasa. Menurut Hermawan Promosi adalah segala aktivitas yang bertujuan mengomunikasikan dan menyampaikan keistimewaan produk kepada sasaran pasar yang dituju[10]. Menurut Hermawan Tujuan utama dalam promosi adalah menginformasikan, mempengaruhi, mengajak serta mengingatkan konsumen akan produk atau jasanya[10]. Menurut Christian A.D Selang Promosi adalah suatu bentuk komunikasi marketing yang merupakan untuk menyebarkan informasi produk, mempengaruhi atau membujuk, meningkatkan sasaran perusahaan dan produknya agar bisa di terima di pasar[4]. Menurut Nisa Novia Avien Christy dan Dwi Widi Pratito Promosi merupakan salah satu dari bauran pemasaran yang menjadi faktor penentu keberhasilan dalam berusaha[3]. Menurut Promosi digunakan sebagai media komunikasi pemasaran yang menggambarkan brand voice sebagai alat membangun kepercayaan dan ikatan relasi kepada konsumen[2]. Menurut Utami Melakukan promosi di media sosial memungkinkan suatu produk untuk dikenal di dunia dan akan menjadi pertimbangan untuk perusahaan global yang akan dicapai oleh perusahaan sebagai alat untuk memasarkan produknya[2]. Menurut Utami Menggunakan media promosi melalui platform internet ataupun media sosial dapat menghubungkan komunikasi antara pemasar tentang produknya atau merek yang dipasarkan di media sosial internet[2].

Menurut Gede Marendra Suatu kegiatan untuk menciptakan komunikasi pemasaran yang bertujuan mengenakan keunggulan produk sehingga mendorong permintaan atau penjualan[5]. Menurut petrus jayabaya dan putu nina mediawati Berkaitan dengan cara-cara produsen mengenalkan produknya kepada konsumen dan khalayak ramai[6]. Menurut Farida Promosi dapat berupa iklam, baliho, media cetak dan media digital yang banyak di lihat oleh khalayak ramai [7]. Menurut Melisa Bauran komunikasi yang digunakan perusahaan untuk mengkomunikasikan kepada orang lain tetang produknya dan meyakinkan mereka agar menggunakan produknya[11]. Menurut Kamaratih Promosi adalah proses mengkomunikasikan 
Journal Economics and Management (JECMA), Volume 2, No. 01, Agustus 2021, p. 10-18

dan memberikan informasi antara penjual dan pembeli atau pihak lainnya dalam sebuah rantai distribusi sehingga berpengaruh pada sikap dan prilakunya [9].

\section{METHODS}

Penelitian ini menggunakan metode kualitatif dengan tipe penelitian deskriptif. Menurut Kamaratih Metode penelitian kualitatif adalah metode yang berdasarkan pada filsafat positivisme atau enterpretif yang digunakan untuk meneliti kondisi objek alamiah dan sebagai lawannya (eksperimen) dimana penelitian berfungsi sebagai instrumen yang menjadi kunci, teknik pengumpulan data dilakukan secara triangulasi atau dalam kata lain gabungan, analisis data bersifat induktif atau kualitatif dan hasil dari penelitian lebih menekankan makna daripada generaliasasi[9].

Penelitian kali ini merupakan termasuk kedalam jenis penelitian studi kasus karena peneliti melakukan observasi mendalam terhadap aktifitas bauran pemasaran yang dilakukan oleh UD. Ratu Sari selain mendeskripsikan bauran pemasaran yang terdapat di perusahaan dan proses produksi. Peneliti menggunakan teknik snowball yaitu sebuah teknik yang dimulai dari informan kunci sebagai informan yang lebih mengetahui secara dalam tentang pelaksanaan dilapangan bauran pemasaran pada UD. Ratu Sari. Dari informasi kunci ini, selanjutnya peneliti akan mengambil informasi lain dari informan lainnya yang lebih luas. Berdasarkan observasi didalam pendahuluan peneliti bertemu langsung dengan pemilik UD. Ratu Sari sebagai informan pertama atau key informan topik yang dibahas di dalam wawancara seputar profil usaha, kegiatan dan pelaksanaan setrategi bauran pemasaran telor asin UD. Ratu Sari dan untuk informan selanjutnya peneliti bertemu dengan Bapak Wahyudi selaku anak dari pemilik UD. Ratu Sari dalam wawancaranya peneliti membahas topik berkaitan dengan promosi dan produk yang ditawarkan UD. Ratu Sari. Informan selanjutnya peneliti memilih konsumen telor asin UD. Ratu Sari untuk memberikan tanggapannya terhadap produk telor asin UD. Ratu Sari. Konsumen yang dipilih adalah Kasmuri dan Ani dengan topik wawancara tanggapan mereka tentang produk telor asin dan alasan memilih produk telor asin dari UD. Ratu sari.

Menurut Kamaratih Pengumpualan data dalam penelitian ini melalui beberapa cara yaitu pertama wawancara mendalam. Wawancara lebih mendalam merupakan suatu cara pengumpulan data atau informasi dengan cara langsung bertatap muka dengan informan yang dituju, dengan tujuan mendapatkan informasi selengkap-lengkapnya tentang topik yang diteliti, Wawancara mendalam dilakukan insentif dan berulang-ulang, wawancara mendalam menjadi alat utama bila dikombinasikan dengan observasi partisipasi[9].

Selanjutnya melakukan melakukan observasi lanjutan dengan dokumentasi. Tahap selanjutnya pemeriksaan data menggunakan ketekunan, triangulasi, pemeriksaan sejahwat dengan diskusi dan analisis kasus negatif. Tahap selanjutnya yaitu analisis data dengan menggunakan analisis domain dan analisis taksonomi. Menurut Kamaratih Analisis domain merupakan sebuah proses analisis untuk memperoleh gambaran umum dan menyeluruh dari objek yang diteliti berdasarkan keadaan sosial yang menemukan berbagai kategori yang didapat dengan beberapa pertanyaan[9]. Menurut Kamaratih Analisis taksmonia merupakan analisis terhadap keseluruhan data yang terkumpul atau dalam kata lain menganalisis data yang didapat pada analisis domain untuk diurai lebih rinci[9]. Berdasarkan keadaan dilapangan yang diuraikan dalam pendahuluan maka proporsi didalam penelitian ini UD Ratu Sari mengimpelentasikan bauran pemasaran yang terdiri produk, harga, tempat dan promosi.

\section{RESULTS AND DISCUSSION}

\section{Produk (Product)}

Produk unggulan pada UD. Ratu Sari adalah telor asin sebagai ciri khas yang paling dikenal masyarakat selain dari bebek dan botok telor asin. Dalam proses pembuatan telor asin 
Journal Economics and Management (JECMA), Volume 2, No. 01, Agustus 2021, p. 10-18

pemilik perusahaan sangatlah detail dari mulai pengurusan kandang bebek yang diternak sendiri dan pakan yang diberikan karena jika cara mengurusnya salah akan mempengaruhi kualitas telor yang dihasilkan, hal ini yang menjadikan kualitas telor asin di UD. Ratu Sari berbeda dengan pesaingnya karena memiliki keunggulan dalam pesaingan berarti memiliki kemampuan lebih dibidang sehingga mampu memenangkan persaingan antar perusahaan terutama perusahaan yang sama-sama dibidang penjualan ataupun produksi telor asin.

Jika produk telor asin yang beredar dipasaran hanya mempunyai ciri khas asin saja berbeda dengan telor asin milik UD. Ratu Sari yang memiliki rasa yang sangat khas di putih telornya karena rasa asin yang didapat sangat pas, tidak terlalu asin dan tidak terlalu hambar dan pada kuning telor berminyak yang membuat kuning telor sangatlah gurih dan hasil produksi seperti ini sangatlah konsisten jadi hampir semua telor bebek yang diolah menjadi telor asin rasanya sama dan terdapat setempel UD. Ratu Sari sebagai tanda telor hasil produksi perusahaannya agar tidak tertukar oleh telor asin kompetitor. Hal ini yang menjadi kelebihan atau keunggulan telor asin UD. Ratu Sari yang membedakan dengan telor asin perusahaan lainnya

Jika tadi dibahas mengenai ciri khas telor asin kini peneliti membahas pengemasannya, UD. Ratu Sari saat ini masih menggunakan pengemasan yang masih sederhana dengan boks berbahan dasar kertas yang lumayan keras sehingga bisa menahan bobot telor asin sampai 10 butir dalam satu boks, selain boks ada juga pengemasan yang menggunakan tomplok ataau wadah yang berbahan dasar anyaman bambu biasanya pengemasan seperti ini yang digunakan untuk dikirim keluar kota yang lumayan jauh dan sampai saat ini perusahaan masih melakukan inovasi-inovasi untuk mencari kemasan yang aman untuk pengiriman via cargo agar tak mudah pecah saat proses pengiriman.

\section{HARGA (PRICE)}

Saat perusahaan sudah mendapatkan nama dipara konsumen atau masyarakat maka perusahaan bisa leluasa menetapkan harga pasar sesuai dengan setrategi yang dilakukan tetapi tetap dengan memperhatikan faktor- faktor penunjang lainnya seperti faktor harga kompetitor. Dalam penentuan harga, UD. Ratu Sari menetapkan harga yang relatif standart karena melakukan pertimbangan harga kompetitor dipasaran yang mematok harga sampai Rp5000 perbutir dan klasifikasi penentuan hargapun menyesuaikan ukuran telor asin perbutirnya., untuk ukuran besar harga Rp3.000, untuk ukuran sedang Rp2.500 dan untuk ukuran kecil Rp2.000 harga ini tentunya di berlakukan untuk wilayah Brebes dan tegal sedangkan untuk harga di wilayah Jakarta, Depok, Bekasi dan tanggerang umunya dijual dikisaran harga Rp5.000 perbutirnya. Hal tersersebut dapat ditunjukkan pada tabel 1 .

Tabel 1. Penentuan Harga UD. Ratu Sari

\begin{tabular}{ccc}
\hline Ukuran & Harga & Wilayah \\
\hline Kecil & 2.000 & Brebes \& Tegal \\
\hline Sedang & 2.500 & Brebes \& Tegal \\
\hline Besar & 3.000 & Brebes \& Tegal \\
\hline Besar & 5.000 & Jakarta, Bekasi, Depok \& Tanggerang \\
\hline
\end{tabular}

Menurut Bapak Rasja pemilik UD “diharga yang yang cukup murah UD. Ratu Sari berhasil menekan biaya produksi karena bahan baku telor asin didapatkan dari peternakan sendiri" 
Journal Economics and Management (JECMA), Volume 2, No. 01, Agustus 2021, p. 10-18

dan Menurut Ani dan Kasmuri pun sebagai konsumen yang berhasil peneliti wawancarai, "Penentuan harga sebanding dengan rasa dan kualitas telor asin yang khas".

\section{TEMPAT (PLACE)}

UD. Ratu Sari dalam menjalankan bisnisnya menggunakan rumah sebagai tempat usahanya sekaligus tempat produksi, saat ini perusahaan tidak mempunyai outlet resmi di daerah Brebes dan Tegal karena penjulan di Brebes dan Tegal memfokuskan pada distribusi kepada pesanan hajatan acara syukuran dan lainnya kebijakan ini diambil karena terlalu banyaknya kompetitor penjual telor asin di kota ini. Sedangkan outlet resminya sendiri ada di daerah jawa barat tepatnya di kota Depok dengan penjualan 24.000 butir perbulan, menurut Wahyudi mengapa pemasaran telor asin lebih di fokuskan di daerah jawa barat karena " kompetitor di daerah sekitar ibu kota sedikit bilapun ada itu telor asin bukan dari Brebes asli jadi rasanya mungkin bisa berbeda, apalagi telor asin dari perusahaan kami mempunyai ciri khas tersendiri yang membuat masyarakat di sekitar ibu kota familiar ketika mencicipi telor asinnya"

Untuk metode pembayarannya sendiri disini UD. Ratu Sari selain menggunakan uang cash, pembayarannya juga menerapkan pembayaran menggunakan M-Banking hal ini tentunya bisa mempermudah pembayaran dan memperlancar penjualan dengan metode pembayaran seperti inipun perusahaan mengimbangi dengan pelayanan yang ramah dan juga jasa antar barang gratis dengan minimal blanja tertentu guna meningkatkan pelayanan dan hubungan baik kepada konsumen.

\section{PROMOSI (PROMOTION)}

Perusahaan yang bergerak dibidang kuliner khususnya kuliner ciri khas suatu daerah pastinya menggunakann metode promosi yang menarik karena promosi merupakan cara perusahaan mengenalkan atau memberi tahu suatu produk yang menurut perusahaan lebih unggul dibanding produk dari kompetitornya. Tujuan dari perusahaan yang bergerak dibidang penjualan produk yaitu untuk mendapatkan laba yang optimal dan peningkatan volume penjualan oleh karena itu perusahaan selalu berupaya untuk melakukan promosi semenarik mungkin untuk mencapai omset yang optimal, menaikan volume penjualan dan memperluas pangsa pasar.

Proses pemasaran yang dilakukan UD. Ratu Sari yaitu supplier ritel dan direct selling. Supplier ritel yaitu dengan cara menjual produk kepada toko-toko ritel yang akan dijual lagi kepada konsumen (mini market, rumah makan padang, warteg, restoran dan pasar) proses ini dilakukan di daerah jawa barat khususnya Jakarta, Depok, Tanggerang dan Bekasi, untuk jumlah permintaan perbulan tidak menentu tapi bisa diambil rata-rata perbulan untuk satu mini market 60 butir, rumah makan padang 40 buit, terdapat lima warteg yang menjadi pelanggan loyal telor asin ini dan satu wartegnya 60 butir perbulan dan sekitar lebih dari 2000 butir perbulan penjulan dipasar, tetapi untuk daerah Brebes dan Tegal menggunakan proses direct selling yaitu menjual produk kepada konsumen langsung biasanya kepada konsumen yang akan digunakan untuk oleholeh dan pada konsumen yang akan digunakan untuk acara hajatan atau syukuran

\section{CONCLUSION}

Dalam pengimplementasian bauran pemasaran yang terdiri dari marketing mix yaitu produk, harga, promosi dan tempat. Produk UD. Ratu Sari penjualan telor asin yang memiliki cita rasa khas yang konsisten rasanya pas di setiap produknya karena diambil dan diolah dari peternakan milik sendiri selain rasa untuk membedakan produk perusahaan dari kompetitor lainnya terhadap setempel perusahaan di telor asin.

Harga telor asin yang di tetapkanpun sangatlah terjangkau dan memberikan pilihan kepada konsumen untuk memilih sesuai dengan budgetnya dan ukuran telor asin yang akan dibeli, Penetapan hargapun selalu mempertimbangkan harga dikompetitor agar tetap bisa bersaing dipasar selain persaingan kualitas. 
Journal Economics and Management (JECMA), Volume 2, No. 01, Agustus 2021, p. 10-18

Tempat, dalam menjalankan bisnisnys UD. Ratu Sari tindak mempunya outlet resmi di Brebes dan tegal, mereka hanya menggunakan tempat peternakan dan tempat produksi sebagai induk perusahaan, Perusahaan mempunyai outlet di Depok dan sekitarnya.

Promosi yang dilakukan UD. Ratu Sari hanya menggunakan kepercayaan antar konsumen yang merasa puas atas produk telor asinnya sehingga disebar luaskan kemana masyarakat luas, hal ini menjadi tantangan perusahaan agar tetap menjaga kepercayan konsumen karena perusahaan belum memikirkn untuk melalukan pemasaran secara digital memalui starup yang ada di Indonesia.

\section{REFERENCES}

[1] R. Rachmawati, J. T. Jasa, D. Produksi, and U. N. Semarang, "Peranan Bauran Pemasaran (Marketing Mix) terhadap Peningkatan Penjualan (Sebuah Kajian terhadap Bisnis Restoran),” J. Kompetensi Tek., vol. 2, no. 2, pp. 143-150, 2011.

[2] H. N. Utami and I. F. A. Firdaus, "Pengaruh Bauran Pemasaran terhadap Perilaku Online Shopping: Perspektif Pemasaran Agribisnis," J. Ecodemica J. Ekon. Manajemen, dan Bisnis, vol. 2, no. 1, pp. 136-146, 2018, [Online]. Available: http://ejournal.bsi.ac.id/ejurnal/index.php/ecodemica/article/view/3407/pdf.

[3] Nisa Novia Avien Christy dan Dwi Widi Pratito, "Penerapan Strategi Bauran Pemasaran pada Usaha Kecil Telur Asin di Kelurahan Tegal Sari, Kecamatan Candi Sari, Semarang Nisa," Ilm. Sos., vol. 21, no. 1, pp. 1-9, 2020.

[4] Christian A.D Selang, "Bauran Pemasaran (Marketing Mix) Pengaruhnya terhadap Loyalitas Konsumen pada Fresh Mart Bahu Mall Manado," EMBA, vol. 1, no. 3, pp. 71-80, 2013.

[5] I. Gede Marendra, F. tabel Kata kunci, B. Pemasaran, K. Pembelian, R. Linear Berganda, and U. Hipotesis, "Pengaruh Bauran Pemasaran (Produk, Harga, Lokasi Dan Promosi) terhadap Keputusan Pembelian Konsumen Di Minimarket (Alfamart Atau Indomaret)," vol. 1, no. 3, pp. 2598-823, 2018.

[6] petrus jayabaya dan putu nina mediawati, "Pengaruh Penerapan Bauran Pemasaran Digital terhadap Minat Beli Pengguna Kereta Api Melalui Aplikasi Mobile KAI Acces," Ris. Manaj., vol. 1, pp. 22-33, 2018.

[7] I. Farida, A. Tarmizi, and Y. November, "Analisis Pengaruh Bauran Pemasaran 7P Terhadap Kepuasan Pelanggan Pengguna Gojek Online,” J. Ris. Manaj. dan Bisnis Fak. Ekon. UNIAT, vol. 1, no. 1, pp. 31-40, 2016, doi: 10.36226/jrmb.v1i1.8.

[8] A. Ulus, "Bauran Pemasaran Pengaruhnya terhadap Keputusan Pembelian Mobil Daihatsu pada Pt. Astra Internasional Manado," J. Ris. Ekon. Manajemen, Bisnis dan Akunt., vol. 1, no. 4, pp. 1134-1144, 2013, doi: 10.35794/emba.v1i4.2872.

[9] R. Kamaratih et al., "Implementasi bauran pemasaran pada syafia plaza jember," pp. 1-15, 2015.

[10] H. Hermawan, "Analisis Pengaruh Bauran Pemasaran terhadap Keputusan, Kepuasan dan Loyalitas Konsumen Dalam Pembelian Roti Ceria Di Jember," J. Manaj. Dan Bisnis Indones., vol. 3, no. 2, p. 152, 2018, [Online]. Available: https://www.google.com/url?sa=t\&rct=j\&q=\&esrc=s\&source=web\&cd=42\&cad $=$ rja\&uact $=8 \&$ ved $=0$ ahUKEwjb5aLXiqXbAhXVb30KHchZDIk4KBAWCC4wA Q\&url=https\%3A\%2F\%2Fjurnal.ugm.ac.id\%2Fjmpf\%2Farticle\%2Fview\%2F29 390\%2F17543\&usg=AOvVaw2mUx8cO0M0VBz16AWxd8MA\%0Ahttp://www .jurnal.

[11] Y. Melisa, "Pengaruh Bauran Pemasaran Ritel terhadap Keputusan Pembelian Ulang Konsumen Mega Prima Swalayan Payakumbuh,” Manajemen, vol. 01, pp. 
Journal Economics and Management (JECMA), Volume 2, No. 01, Agustus 2021, p. 10-18

1-20, 2012, doi: 10.4324/9781315614878-20.

[12] R. R. ,. R. S. A. I. Andi Yulianto, “Analisis Positioning Operator Seluler dan Strategi Pemasaran Untuk Memenangkan Pasar di Wilayah Yogyakarta," Journal of Economic and Management (JECMA), pp. 33-45, 2020. 